\title{
De Viridiana de Luis Buñuel a Carmen de Carlos Saura. Conversaciones sobre montaje cinematográfico con Pedro del Rey
}

\section{From Viridiana by Luis Buñuel to Carmen by Carlos Saura. Conversations about cinematographic montage with Pedro del Rey}

\author{
Guillermo López Aliaga \\ Universidad Miguel Hernández de Elche, España \\ guillermo.lopeza@umh.es \\ https://orcid.org/o000-0002-7106-7267
}

\section{Resumen:}

Diálogo con el célebre montador cinematográfico Pedro del Rey del Val en torno a su extensa y prolífica carrera en la industria cinematográfica. Desde sus comienzos en la industria como ayudante de montaje a finales de los años cuarenta, Pedro del Rey ha sido responsable del montaje de algunos de los títulos más emblemáticos y exitosos del cine español durante la segunda mitad del siglo XX. En sus más de doscientas películas ha trabajado a las órdenes de directores tan célebres como Luis Buñuel, Carlos Saura, Vicente Escrivá, Francisco Regueiro, Jaime Chávarri, Julio Diamante o Basilio Martín Patino, entre muchos otros. Además, a partir de 1995 y durante doce años ha sido profesor de Montaje de segundo y tercer curso en la Escuela de Cinematografía y del Audiovisual de la Comunidad de Madrid (ECAM). Un excepcional recorrido de primera mano por la historia de nuestro cine y por uno de sus oficios más importantes y, a la vez, desconocidos para el gran público, el montaje cinematográfico, a través del punto de vista y las experiencias vividas por uno de sus principales protagonistas.

\begin{abstract}
:
Dialogue with the famous film editor Pedro del Rey del Val about his extensive and prolific career in the film industry. Since his beginnings in the industry as an assistant editor in the late 1940s, Pedro del Rey has been responsible for the editing of some of the most iconic and successful titles in Spanish cinema during the second half of the 20th century. In his more than two hundred films he has worked under the orders of such famous directors as Luis Buñuel, Carlos Saura, Vicente Escrivá, Francisco Regueiro, Jaime Chávarri, Julio Diamante or Basilio Martín Patino, among many others. In addition, from 1995 and for twelve years he has been a second and third year Film Editor teacher at the School of Cinematography and Audiovisual of the Community of Madrid (ECAM). An exceptional first-hand journey through the history of our cinema and through one of its most important and, at the same time, unknown to the general public, the cinematographic montage, through the point of view and the experiences lived by one of its main protagonists.
\end{abstract}

Palabras clave:

Montaje; Películas; Historia; Cinematografía; Pedro del Rey; Viridiana

Keywords:

Editing; Films; History; Cinematography; Pedro del Rey; Viridiana 


\section{Introducción}

Pedro del Rey del Val es uno de los montadores más veteranos y prolíficos de la industria cinematográfica española. Desde sus comienzos como aprendiz de montaje a finales de los años cuarenta del pasado siglo, accedió al mundo profesional de la mano de quien fuera su cuñado, y único maestro, el también montador José Antonio Rojo. A lo largo de su carrera ha participado en más de ciento cincuenta películas, trabajando a las órdenes de sesenta y cuatro directores, entre los que destacan algunas personalidades insignes de nuestro cine como Luis Buñuel, Carlos Saura, Basilio Martín Patino, Marco Ferreri, José María Forqué, Francisco Regueiro, Vicente Escrivá o Jaime Chávarri, entre muchos otros.

Tras una etapa formativa, en la que desempeñó el trabajo de meritorio, auxiliar y ayudante de montaje, su primer proyecto como montador jefe en una producción cinematográfica lo encontramos en Río Guadalquivir (1957), una producción hispano italiana dirigida por Eduardo Manzanos y Primo Zeglio. Desde este momento, la carrera profesional de Pedro del Rey en el campo del montaje cinematográfico tuvo un ascenso fulgurante, pasando a convertirse en un indiscutible referente en la industria de la época. A comienzos de los años sesenta, tras realizar el montaje de numerosos y exitosos títulos de nuestro cine como, por ejemplo, Los Golfos (1960) o El cochecito (1960), participa a las órdenes del célebre Luis Buñuel en el montaje de una de sus obras más reconocidas y laureadas, Viridiana (1961), galardonada con la Palma de Oro en el Festival de Cannes de ese mismo año. Volvería a colaborar con este autor en otro de sus títulos emblemáticos como es Tristana (1970), pasando a convertirse, en palabras del propio Buñuel, en su montador de confianza en España.

A lo largo de los años sesenta, setenta, ochenta y noventa continúa su extensa trayectoria profesional realizando el montaje de títulos tan célebres de nuestro cine como Atraco a las tres (1962), La gran familia (1962), La tía Tula (1964), Nueve cartas a Berta" (1965), El Anacoreta (1976), Carmen (1983), El amor brujo (1986), El dorado (1988) o La Celestina (1996). Además del montaje de largometrajes de ficción, también ha trabajado a lo largo de su carrera en 
numerosos documentales como Morir en España (1965), España puerta abierta (1972) o The Secret Life of Sergei Eisenstein (1987) y series de televisión como Cuentos y leyendas (1970-1972), Los gozos y las sombras (1982) o Proceso a Mariana Pineda (1984). Así pues, nos encontramos ante uno de los montadores más respetados de nuestro cine, un auténtico referente en este campo profesional por su conocimiento de un oficio, el montaje cinematográfico, el cual define como el arte de contar ensamblando, en tiempo y medida, imágenes y sonidos, de tal modo que esa unión ponga en funcionamiento la historia escrita en el guion, asegurando ante todo la continuidad del relato. Una profesión que, pese a ser fundamental en la creación de cualquier obra cinematográfica, sigue siendo, en muchas ocasiones, una gran desconocida para el público, frente a la visibilidad y reconocimiento de otras disciplinas como la dirección o la interpretación.

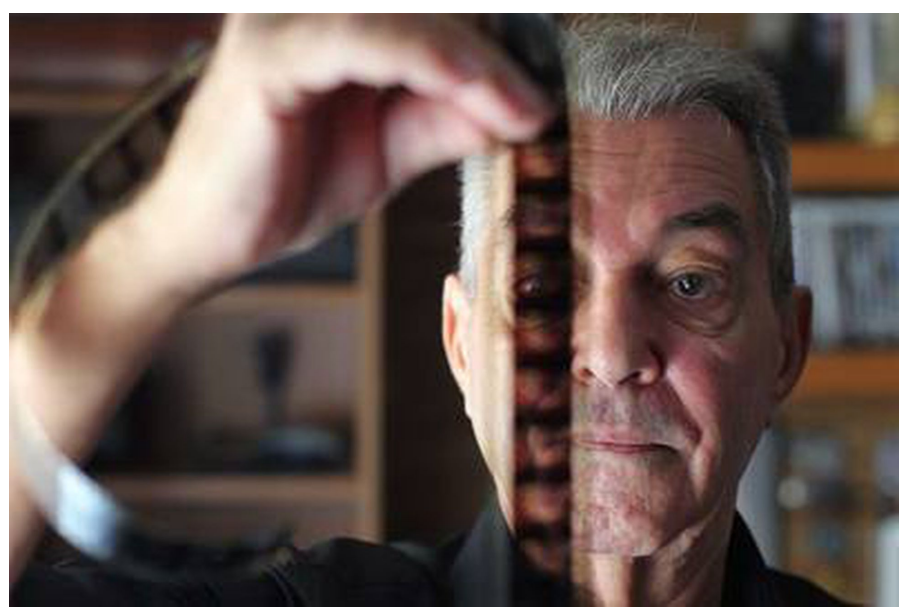

Imagen 1. Pedro del Rey observando el celuloide. Fuente: https://elpais.com/diario/2010/10/19/madrid/1287487469_850215.html

Durante un diálogo de tres horas a través de una aplicación de videoconferencia por Internet, debido a la situación de pandemia actual, Pedro del Rey compartió con nosotros un viaje por su dilatada trayectoria en la industria, relatando experiencias y anécdotas de la creación de algunos de los más importantes títulos en la historia del cine español, así como sus conocimientos sobre un oficio fundamental en la creación de cualquier película, el montaje cinematográfico. 


\section{Los comienzos en la industria cinematográfica.}

\section{¿Cómo conoces el mundo del cine y el montaje cinematográfico?}

Llegué al mundo del cine allá por el año 1945, aproximadamente, cuando mi hermana se hace novia de José Antonio Rojo ${ }^{1}$, que después fue mi cuñado, y él me hablaba siempre del montaje, pero a mí lo que verdaderamente me gustaba era la mecánica.

En mi casa siempre hubo un taller mecánico y mi madre siempre repetía, "ya estoy harta de lavar grasa", pero yo, siguiendo en lo que me gustaba me coloqué en una fábrica de metalurgia, donde empecé como aprendiz de tornero. Cuando lo abandoné era oficial de segunda y, curiosamente, el que había sido mi maestro, se había trasladado a una empresa que empezaba de nuevo y en la él era quien contrataba al personal. Un día me llamó y me dijo "vente conmigo, te necesito", y yo lo estaba esperando, pero llegó el verano y me marché con mi familia al mar. Por aquel entonces, mi madre me decía, “iestás seguro de abandonar a Lladró?”, y al mismo tiempo mi cuñado me insistía, ¿̇por qué no te vienes conmigo al estudio y ves lo que es el montaje? Al fin fui allí y me pareció que aquello era un mundo de locos, con todas aquellas cajas, con aquellas películas colgadas, con todo aquel lío... Empecé a darle vueltas a la cabeza y, al fin cambié el torno por la moviola, te estoy hablando del año 1947. Entonces, él estaba montando Mare Nostrum (1948)², con Fernando Rey y María Félix, dirigida por Rafael Gil, con un Alfredo Fraile de director de fotografía, con Enrique Alarcón como decorador, era uno de los principales equipos españoles en aquel momento.

De ese modo empezó mi vida en el cine y el montaje, recogiendo cestos, cogiendo trozos de película. Poco a poco fui avanzando, primero pasé de meritorio a auxiliar, después de auxiliar a ayudante y, por último, cuando estábamos haciendo Río Guadalquivir (1957)3, entonces yo era ayudante, un sábado fui a

\footnotetext{
1. José Antonio Rojo Paredes (1923-1995) fue un montador cinematográfico español. A lo largo de su trayectoria participó en más de doscientas películas como, por ejemplo, La noche del sábado (1950), Un caballero andaluz (1954), Los ladrones somos gente honrada (1956), Las chicas de la Cruz Roja (1958), Plácido (1961) o La sombra del ciprés es alargada (1990), por la que obtuvo la Medalla del Círculo de Escritores Cinematográficos al Mejor montaje.

${ }^{2}$. Coproducción hispano-italiana producida por Suevia Films que adapta la novela homónima de Vicente Blasco Ibáñez.

3. Película dirigida por Eduardo Manzanos y Primo Zeglio y co-producida por Memphis
} 
cobrar a la oficina y me dice el administrador, "tengo tu talón para ti, pero no para tu cuñado”, “¿y eso por qué?”, y me dice, "eso lo tienes que hablar con el señor Manzanos, así que pasa al despacho”. Eduardo Manzanos, el productor, que era una persona extraordinaria, me dijo, "mira, Pedro, te voy a ser muy sincero, José Antonio no se ha ocupado para nada de la película (Río Guadalquivir), y como quien más ha hecho has sido tú, he decidido que seas tú quien te hagas cargo de ella como montador". Me quedé temblando. Llegué a casa, por aquel entonces yo vivía con mis hermanos, y le dije a mi cuñado, "mira, esto es lo que me dice Eduardo", y él me contestó, "perfecto, este es el momento que yo estaba buscando, porque tú estás ya en disposición de tirar para adelante". Rio Guadalquivir fue mi primera película como montador jefe.

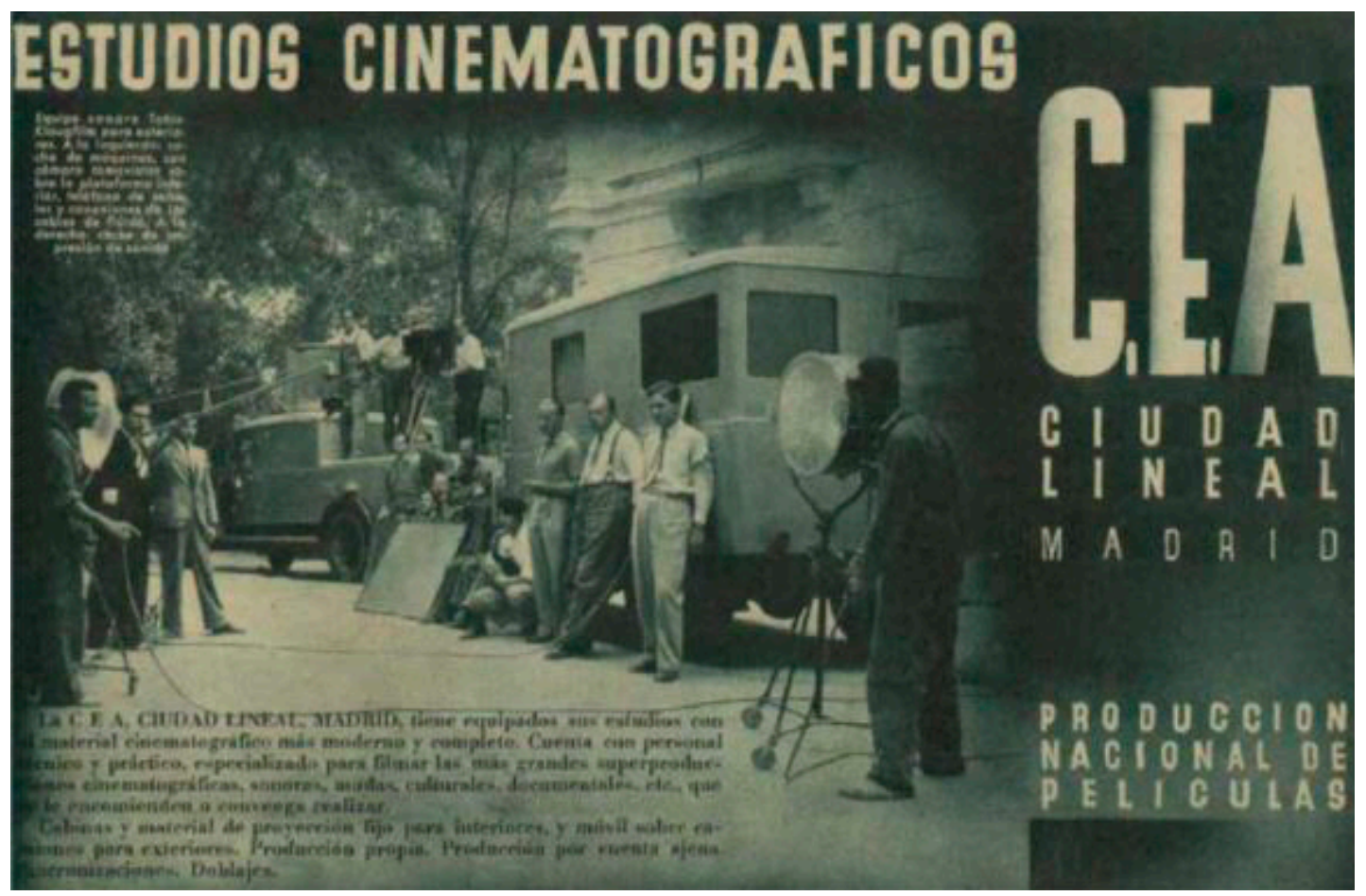

Imagen 2. Publicidad de los estudios cinematográficos CEA (Cinematografía Española y Americana). Fuente: https://legadoarturosoria.es/la-ciudad-lineal-en-el-cine /

En Barcelona comenzaba el rodaje de Carta a Sara (1956)4, con un guion de Juan Antonio Bardem, co-producción hispano italiana producida por Dario Sabatello,

Films y Unión Films.

${ }^{4}$. Coproducción hispano-italiana producida por Dario Sabatello, Romana Fillm y Union Film 
Romana Film y Union Film y dirigida por Leonardo Bercovici, Claudio Gora y Eduardo Manzanos, que me llamó nuevamente para decirme "ya tienes la siguiente película”. Anteriormente, en Suspenso en Comunismo (1956)5, otra película de Union Films, tenía dos versiones, una en Cinemascope, que montó mi cuñado, y al mismo tiempo se rodó la misma versión en $35 \mathrm{~mm}$ en normal. Cuando se terminó de montar la versión en Cinemascope, mi cuñado me dijo, "mira, en tus ratos libres quiero que montes la versión normal”. De meritorio, tardé diez años en llegar a ser montador.

En aquella época, para poder acceder a la profesión cinematográfica, el Sindicato del Espectáculo exigía un certificado del meritoriaje efectuado en, al menos, tres películas. Este certificado debía de ir firmado por el responsable de la especialidad y el jefe de producción de cada una de las pelkículas, y partir de ese momento, ya era posible contratarte como auxiliar, categoría en la que debían hacerse un mínimo de cuatro películas para obtener el carnet de ayudante. Los ayudantes de montaje eran las primeras personas, despues del ayudante de cámara, en tocar un negativo impresionado y recién revelado porque el ayudante de montaje tenía que descartar en el laboratorio, separando las tomas buenas de las malas e, incluso, montar por claquetas, con sonido fotográfico, porque al terminar el rodaje cada jornada, había que visionar el trabajo del día anterior en copia estándar. Y ese era el trabajo directo que tenía que hacer el ayudante al medio día en el mismo laboratorio.

La última película que yo descarté fue Teatro Apolo (1950)6 ${ }^{6}$ Aquel día terminé mi trabajo a las dos y media de la tarde en la calle Diego de León $n^{\circ} 45$, en los laboratorios Madrid Film, y me fui a una finca que tenían mis tíos en los alrededores de Madrid. En aquella época había restricciones de luz y se empezaba a rodar a las siete de la tarde. Cuando llegué al estudio, me encontré a todo el mundo llorando y señalando una columna de humo en Madrid que llegaba al

y dirigida por Leonardo Bercovici, Claudio Gora y Eduardo Manzanos.

5. Comedia producida por C.E.A y Unión Films, dirigida por Eduardo Manzanos, y protagonizada por Alfredo Maya, Antonio Vico, Juanjo Menéndez y Carlota Bilbao, entre otros.

${ }^{6}$. Musical dirigido por Rafael Gil, producido por Suevia Films, y protagonizado por Jorge Negrete, María de los Ángeles Morales y Juan Espantaleón, entre otros. 
cielo. Había ardido los laboratorios Madrid Film. Allí se quedaron mis tijeras, mis guantes y mi lupa. Fue un desastre nacional porque desaparecieron cientos de películas del cine mudo, del primer cine hablado, una cosa espantosa7.
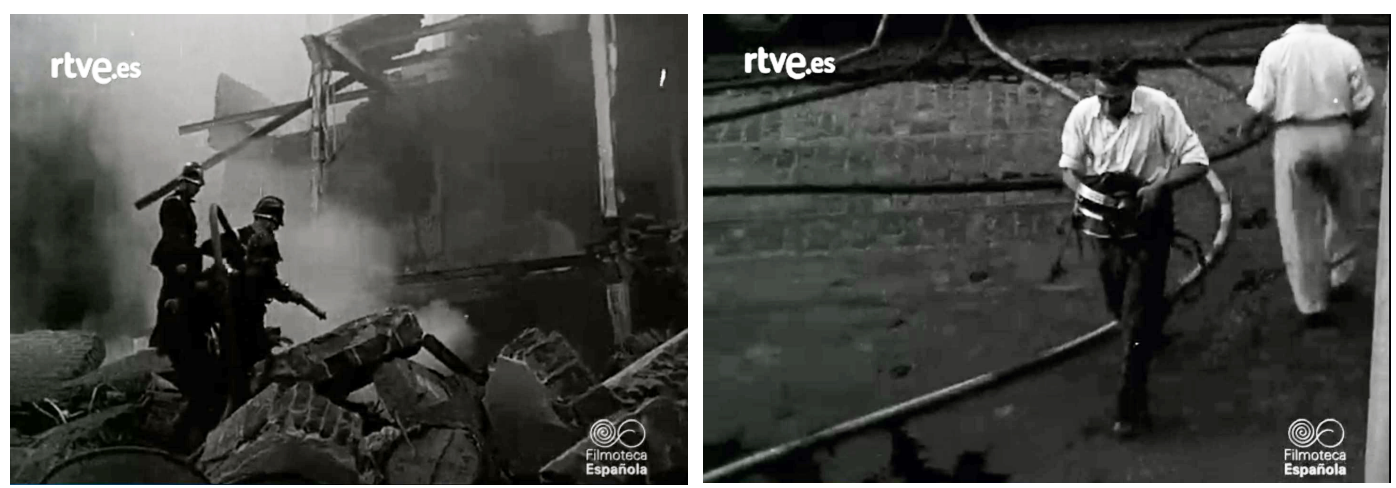

Imagen 3. Imágenes del incendio en los laboratorios Madrid Film extraídas del NODO nº 397 (14-08-1950) Fuente: https://www.rtve.es/filmoteca/no-do/not-397/1465225/

\section{Consideraciones generales sobre montaje cinematográfico}

\section{¿Cómo definirías tu profesión?, ¿cómo definirías el montaje cinematográfico?}

El montaje cinematográfico es el arte de contar ensamblando en tiempo y medida imágenes y sonidos, de tal modo que esa unión ponga en funcionamiento la historia escrita en el guion, asegurando ante todo la continuidad del relato. Esa es la definición que yo doy porque es en lo que creo y es lo que he hecho yo toda mi vida. Siempre he hecho hasta cuatro lecturas de guion antes de empezar una película, la primera para conocer la historia, después para ir identificando y marcando personajes, después para marcar situaciones y, más tarde, volvía a la primera lectura, y volvía a estudiar secuencia por secuencia. Cuando me sentaba frente la moviola, siempre tenía el guion a mi lado, antes de empezar a marcar lo volvía a leer, y releer, a partir de ese momento, atacaba directamente y decía, este plano tiene que ir aquí, ¿̇por qué?, porque este plano que es de inicio a ha de ir

\footnotetext{
${ }^{7}$. El incendio de los laboratorios Madrid Films tuvo lugar el 1 de agosto de 1950. Además de la pérdida de vidas humanas, este siniestro provocó la destrucción de gran cantidad de material fílmico de producciones españoles anteriores a los años cuarenta. Por aquel entonces, este material era altamente inflamable.
} 
este otro como comienzo de consecuencia, y ¿̇por qué metes este plano de este señor escuchando? Porque es importante que este personaje más adelante sea descubierto, todo esto es la trama que va uniendo plano a plano, para crear una secuencia enriquecida con diferentes encuadres, que producirá esa sucesión de imágenes que habrá de mantener el interés del espectador.

\section{¿Cómo consideras que ha de ser la relación entre el montador o montadora con el director o directora?}

Yo puedo decir que, de los sesenta y cuatro directores, para mí fueron sesenta y cuatro amigos, y cuando pienso en alguno de ellos, y cuando pienso en alguno de ellos, que ya no están, lo único que hago es entristecerme porque yo los he querido y admirado mucho a todos, desde el primero al último. Igual que te he dicho de Carlos, te puedo decir, por ejemplo, de algún otro director director, Don Manuel Mur Oti. Yo no había trabajado nunca con él, pero aquí decía todo el mundo que era un excéntrico. Un buen día me llamaron para decirme si quería hacer una película que se estaba rodando en San Juan de Puerto Rico y que dirigía Manuel Mur Oti, El Escuadrón del Pánico (1965) ${ }^{8}$. Yo estaba terminando de mezclar "La tía Tula" (1964)9 en aquel momento, y acepté el ofrecimiento. Me dijeron que el señor Mur Oti había pedido que me fuera a San Juan una semana para conocerme y ver juntos el material rodado, así que cogí un avión y me presenté en San Juan de Puerto Rico. Me encontré con una persona super inteligente y entrañable de verdad. La primera noche que estuve allí me dice, "mira Pedro, lo primero que vamos a hacer antes de hablar de la película es que te voy a enseñar San Juan”. Él conocía el Caribe mejor que los que había nacido allí y me enseñó todo San Juan de Puerto Rico, los grandes hoteles, los grandes restaurantes, todo. Yo he trabajado siempre solo, exceptuando con un director, que es Don Luis Buñuel. Me traje el material de San Juan y empecé a montar tranquilamente, y cuando llegó Don Manuel, me faltaba mucho material que tenía que llegar de San Juan,

\footnotetext{
${ }^{8}$. Película española de género bélico, dirigida por Manuel Mur Oti y producida por Caribbean Films y Trefilms, y protagonizada, entre otros, por Leo Anchóriz, José Manuel Bonilla, Ulises Brenes.

${ }^{9}$. La tía Tula es una película española del año 1964 dirigida por Miguel Picazo y producida por Surco Films. La película, que adapta una obra literaria del escritor Miguel de Unamuno, ganó el Premio a mejor película y a Mejor director en el Festival de San Sebastián del año 1964.
} 
pero en una revuelta por aquellos países se extraviaron diez cajas de ciento cincuenta metros de película impresionada sin revelar. Don Manuel corrió una aventura tremenda hasta encontrarlas en un sótano y, de forma extraña, le costó un dineral. Cuando llegó a Madrid se reveló el material y afortunadamente estaba intacto, perfecto. No faltó nada. De la misma manera, otro buen día conocí a Mariano Ozores. Yo conocía ya a José Luis Ozores, "Peliche"10, que era un actor maravilloso. Hice la primera película de Mariano, después hice otras con él, una persona increíble, gran amigo, y te puedo decir así todos, Basilio Martín Patino, un gran estudioso del cine y gran persona, Manolo Summers, otro portento de persona. De la misma manera puedo hablar de Picazo, otra persona entrañable. Es que para mí los directores, además de compañeros, formaban parte de la familia. Cualquier tipo de discusión que puedas tener con el director es una cuestión de gustos y pareceres. Yo lo veo de esta manera, tú lo ves de la otra... Por ejemplo, te puedo contar que, haciendo la última película de Jaime Chávarri, "Sus ojos se cerraron y el mundo sigue andando" (1998), tuvimos que ir a doblar unas escenas a Buenos Aires, porque algunos actores vivían allí. Un día íbamos por la avenida Corrientes camino al hotel e íbamos hablando sobre una secuencia que no nos encajaba. Y de pronto nos paramos y Chávarri dice, "sabes lo que te digo, en cuanto llegues a Madrid, lo primero que tienes que hacer es mandar la secuencia al cesto.”. Y suprimimos aquella secuencia. Jaime Chávarri es otro buen amigo, y así, hasta sesenta y cuatro. Curiosamente, cuando he trabajado con directores extranjeros, por ejemplo, haciendo películas con italianos, me he llevado maravillosamente con los italianos. Después, viví dos años en Suiza, trabajando de montador en Polivideo. Hablando con los realizadores sobre esta o aquella secuencia yo siempre preguntaba si les parecía bien como está montada y ellos siempre contestaban lo mismo "si a ti te parece bien..." y yo les contestaba "no, no, tú eres el director y tienes que darme tu opinión", pero al llegar a Polivideo lo primero que me dijeron fue "mira Pedro, aquí en la empresa el realizador realiza, el montador monta, quiere decirse que, si tú no estás de acuerdo con lo que diga el director, a ti te tiene sin cuidado, el que manda en

${ }^{10}$. Apodo cariñoso con el que se conocía al actor José Luis Ozores. 
montaje eres tú”. La primera película que hice para televisión Il giocatore invisibile (1985) ${ }^{11}$, efectivamente, se presentó el director el primer día, aunque le habían dicho que no podía asistir al montaje. Se presentó en montaje y dijo, “Pedro, yo quería presentarme... ¿̇me voy?”, y le dije, “no, por favor, quédese”. A partir de ese momento nos convertimos en grandes amigos. Tristemente ha desaparecido, pero me sigo mandándo mails con sus hijos y con toda la familia, además de gente de la empresa. De verdad que yo he tenido una relación muy estrecha con los directores y lo he pasado francamente bien.

\section{¿Recuerdas algún caso concreto en el que, el fruto de esta negociación enre director-montador, contribuyera a crear una solución no contemplada y que mejorara la propuesta inicialmente?}

Montando Tierra brutal (1962), estaba un día con Michael Carreras, el director y, al mismo tiempo, coproductor. Había un plano en el que Richard Basehart desenfundaba el revolver para matar al contrario, y el director me dice, "dale para atrás Pedro”, yo le doy para atrás, y me dice, “dale para adelante”, yo le doy para adelante, y yo decía, "pero bueno, este está hoy un poco bebido o qué”, y de pronto me dice,"ahora el plano tres cuartos también”. "Píde al laboratorio el negativo esos dos planos porque me los voy a llevar a Londres", y le digo, “¿me puedes explicar por qué" y me dice, "sí, mira, vamos a cambiar este personaje, en vez de ser un asesino va a perdonarle la vida al tipo con el que se va a enfrentar”, y digo, "no es posible, tal y como lo tenemos rodado". Y me dice, "sí, porque vamos a rodarlo marcha atrás, y entonces, lógicamente, está desenfundando el revólver y lo que va a hacer es guardarlo, lo ha sacado de la pistolera y lo que va a hacer es volver a meterlo, el primer plano lo tienes también para hacer el mismo juego con la inversa”. Aquel hombre se llevó los negativos a Londres, volvió con los negativos nuevos de ambos planos, lo montamos y así están en la película. Aquel desconocido recurso para mi hasta entonces lo he empleado en diferentes ocasiones con resultados podríamos decir asombrosos, en una película de Vicente Escrivá, El Virgo de Visanteta (1979) ${ }^{12}$. Estuve muchos años trabajando con

\footnotetext{
${ }^{11}$. Il giocatore invisibile es una película italiana dirigida por Sergio Genni y protagonizada, entre otros, por Marco Bonetti, Adolfo Celi y Roberto Herlitzka.

${ }^{12}$. El Virgo de la Visanteta es una comedia española dirigida por Vicente Escrivá y producida
} 
Escrivá. La pelicula se rodaba íntegramente en Valencia, yo estaba montando en Madrid, todas las noches hablábamos por teléfono, “¿qué tal?, "bien, tal, todo bien...” Y entonces, me dijo, "bueno, pues nada, la mayor parte del equipo ya se ha ido para Madrid”, digo, “¿cómo?”, dice, “sí, que se han ido para Madrid porque ya mañana terminamos”, digo, “oiga, Don Vicente, ¿usted sabe que yo tengo seis rollos de película montados?”, "bueno, bueno, usted está borracho, seguro que no ha montado nada, como yo no estoy allí, bueno, pues nada, mañana nos vemos”, y al día siguiente, a las cuatro de la tarde, llega a los estudios Cinearte ${ }^{13}$ y dice, "bueno, a ver, ¿qué pasa?”, y le digo, "mire, uno, dos, tres, cuatro, cinco y seis rollos, esto es lo que he estado haciendo", "bueno, pues vamos a ver el primer rollo". La pelicula arrancaba con una procesión nada mas empezar, y me me dijo “pare, este plano está cortísimo”, y le digo, “ah, ¿sí??”,"recorte”, y viene el ayudante y me hace así con la mano, cinco fotogramas, "no es posible, pues habrá otra toma...” “¿segunda toma?” "No hay segundas tomas...” Bueno, y así vamos viendo rollo a rollo, mientras el repetía, "no es posible, no es posible”, "pero, ¿qué es lo que ha pasado, Pedro?”, "pues no lo sé...” Pero ya habíamos llegado al rollo tres o cuatro, donde había un sacristán que estaba cantando en la Iglesia con todo el pueblo presente, teníamos un travelling desde atrás que llegaba hasta plano corto de este hombre. De pronto, detengo la moviola y empiezo a dar marcha atrás y a dar marcha adelante, y ya llega un momento que dice Escrivá, “¿qué quiere que me maree?”, digo, no, es que estoy dándole vueltas a algo. Y me dice, “usted sabrá lo que hace, pero desde luego, la película tiene que tener nueve rollos”. Digo, “ah, ¿me dice usted a mí, que qué hago yo?”, “ah, yo no sé, pues invente usted”. Y le pregunto, “¿usted qué tal escribe marcha atrás?”, imagínate, era un Premio Nacional de Literatura14, "bueno, no empecemos ya con bromas, ¿qué coño quiere usted?”, digo, "pues se lo voy a decir claramente, ¿usted ve cómo avanza hacia Paco Sanz el travelling y llegamos a plano corto?”, "sí señor”, "bueno, pues ahora

por Aspa Producciones Cinematográficas S.A. La película está protagonizada por María Rosaria Omaggio, Antonio Ferrandis, José Sancho y Joselé Román.

${ }^{13}$. Estos estudios iniciaron su actividad bajo el nombre de Estudios Linnartz en el año 1933, y posteriormente operaron, como Estudios Iberofilm. En 1934 pasan a adoptar la denominación definitiva de Cinearte, bajo la que siguen trabajando actualmente en Madrid.

${ }^{14}$. Vicente Escrivá ganó el Premio Nacional de Literatura en 1947 con su obra "Jornadas de Miguel de Cervantes". 
mire, si yo doy marcha atrás, mire los movimientos labiales de Paco Sanz, sigue hablando, pero lo hace marcha atrás, igual que va la cámara, usted me puede hacer un diálogo...”, "ah, yo sí... espere un momento”, a ver...”, coge un papel y un lápiz, empieza a escribir y continua con el cántico exactamente igual. Y con esto, ¿qué es lo que ganamos?”, digo, “de momento, hemos ganado un plano bastante largo, y entonces ¿ahora qué es lo que ocurre?, vamos a ver los espectadores, cómo los tenemos y a ver qué podemos hacer”. Bueno, pues empezamos a jugar con todo aquello... y él decía una cosa, “¿y la calidad fotográfica?”, digo, "mire, en este momento, el intermediate positivo es maravilloso...", "bueno, bueno, que nos hagan este plano". Y nos lo hicieron marcha atrás en la truca de Fotofilm y lo recibimos. Y una tarde, llega el operador de la película y pregunta, “¿qué tal?, ¿cómo van?", "bien, bien”, y dice, "precisamente le queríamos enseñar a usted, que se nos ha roto un plano, mire usted a ver qué calidad nos han hecho, porque no estoy seguro si está bien...” cuando lo ve el operador en pantalla dice, “¿y qué tiene usted que decir de este plano? Si esto tiene una calidad estupenda...”. No opinó sobre si iba marcha atrás o marcha adelante, no, no, él dijo la calidad que tenía, y entonces dijo Escrivá, "pues ċsabe usted una cosa?, que ese plano lo ha rodado Pedro", "no, no, perdone, ese plano lo he rodado yo...", "no, nosotros rodamos ese plano en Valencia y nos acercábamos a Paco y Pedro ha rodado este plano, del plano corto al plano largo. Lo ha rodado aquí", "no es posible", "bueno, pues nada, no es posible...”. Pues conseguimos nueve rollos de película.
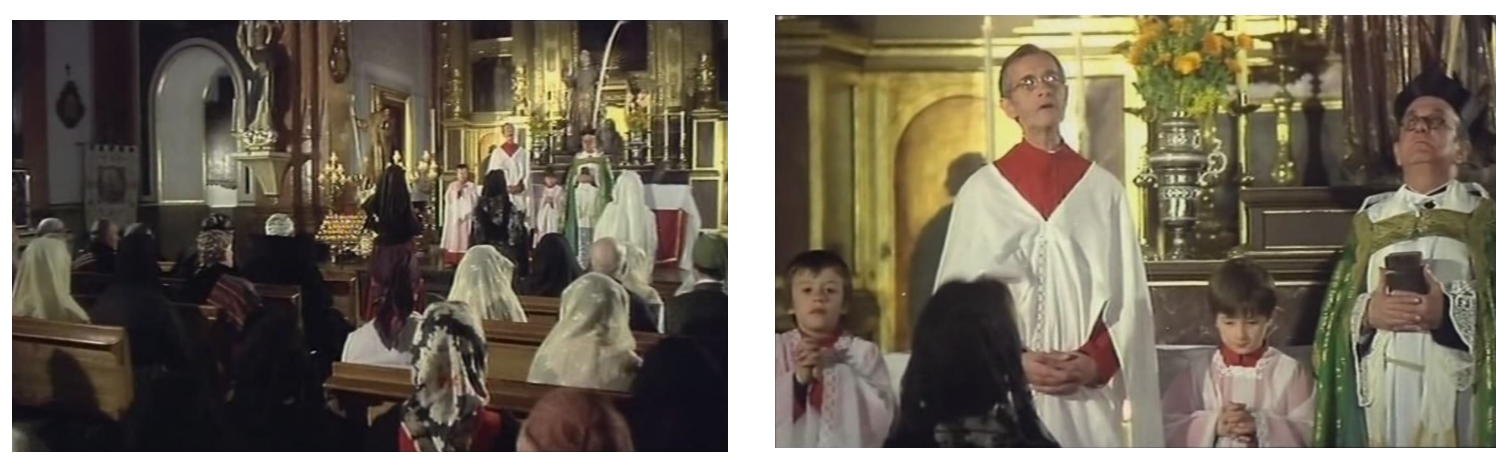

Imagen 4. El Virgo de Visanteta (Vicente Escrivá, 1979). Gracias a los trucos de montaje consiguió aumentarse el metraje de la película hasta llegar a los nueve rollos, como quería su director. 
Trabajando con Gerardo Vera en La Celestina (1966) ${ }^{15}$, había un momento en el que aparecía un personaje de un modo un tanto extraño... Yo hubiera necesitado en aquel momento un plano más en corto, pero bueno, ya no era posible hacerlo. Y yo, cada vez que llegaba a esa secuencia, decía, “¿qué podríamos hacer aquí?”. Entonces, hice una cosa que ya había hecho anteriormente, me fui viendo todo el material anterior y posterior ya montado a ver si encontraba un plano del personaje que pudiera aparecer allí. Pero da la casualidad que el personaje había cambiado de vestuario y, entonces, yo tenía un problema grave. Y hablando con Gerardo le dije, “¿qué te parece si para entrar aquí hacemos una cosa?, cogemos este plano, yo me voy al laboratorio y les digo que en la truca me encuadren al personaje por el cuello, con lo cual, me evito hombros y camisa y este plano lo puedo utilizar, como escucha dentro de la secuencia”. Gerardo dijo, "Increible". Lo de rodar desde la sala de montaje en combinación con la truca del laboratorio lo he hecho en distintas películas.

\section{El trabajo en la sala de montaje de Pedro del Rey}

\section{Me gustaría, Pedro, cómo no, hablar de tu trabajo con Luis Buñuel en "Viridiana" (1961).}

Pues mi encuentro con Luis Buñuel fue un poco raro, porque yo había hecho Los Golfos (1960) y El Cochecito (1960) ${ }^{16}$ con Films 59, y entonces, el director de producción, Gustavo Quintana, pues me llama un día y me dice, “oye Pedro, tengo una película para ti, pero vas a tener que pagar por hacerla porque el director es Luis Buñuel”, digo, "hombre esto ya es otra cosa...” "sí, sí, mira, estás citado con él mañana a las siete de la tarde en la Calle Arenal que hemos montado una oficina exclusiva para la película. “¿Cómo?”, “sí, sí, que quiere verte”, y a las siete de la tarde yo entré en el despacho donde estaba Don Luis, me presentaron, y dijo a la

\footnotetext{
15. Película dirigida por Gerardo Vera y adaptada por Rafael Azcona desde la obra de mismo nombre escrita por Fernando de Rojas.

${ }^{16}$. El Cochecito es una película española dirigida por Marco Ferreri, con guion de Rafael Azcona y del propio Marco Ferreri, protagonizada por José Isbert, Pedro Porcel, María Luisa Ponte o José Luis López Vázquez, entre otros. Gano el Premio de la Crítica en el Festival de Venecia del año 1960.
} 
persona que me acompañaba, "entregue un guion a Don Pedro”, y me dice a mí, “creo que vamos a colaborar, léase usted el guion, venga mañana y me da su opinión, le espero mañana a la misma hora”. Leí el guion y, al día siguiente, a las siete de la tarde, llegúe nuevamente al despacho que ocupaba Don Luis Buñuel. A modo de saludo preguntó, “¿qué le ha parecido el guion?”, “me ha gustado muchísimo, lástima que esta película no se pueda hacer en España”. ¿Qué dice usted?, digo, “que esta es una película blasfema...”, y dice, "pero si es una película blanca por completo. No tiene nada en absoluto, fíjese usted cómo tratamos la religión, cómo tratamos a los mendigos...”, digo, “ya, ya, pero esta película...”, dice, "bueno, mire usted, el rodaje comienza mañana en la quinta del Pardo, le espero a usted a las ocho de la mañana”, digo, “¿cómo?”, dice, “sí, sí, que le espero a usted a las ocho de la mañana en el set”. Llegué a la Quinta a las ocho menos cuarto, allí estaba él, "hola, buenos días don Pedro", aquel día ya me dijo don Pedro, "buenos días, don Luis", de pronto, viene Juan Luis, que era segundo ayudante con Pepe Puyol, que era el primer ayudante, y le dice, “oye papá, que la script no ha llegado”, dice, “¿ah no?, pues que le den el libro de cámaras al montador", muy sorprendido, yo me digo, esto es inaudito. "Pdro, que dice el jefe que como no hay script, que te ocupes tú del libro de cámaras”. Empiezo a rellenar fechas y el decorado cuando aparece la script toda acalorada, "perdónenme que me he dormido, no sé qué...” Ese fue el primer fía de rodaje.

A partir de ahí, todos los días, cuando se rodaba en plató, yo bajaba al rodaje, ya no volvió a citarme nunca más en exteriores. Cuando mis ayudantes tenían preparado el material rodado el día anterior le decía, "lista la proyección”, y él me contestaba, "bien, cuando yo acabe de preparar el siguiente plano lo veremos", siempre lo veíamos él y yo solos, ni el señor Aguayo podía ver el rodaje del día antes de que él lo viera, después lo podía ver el equipo entero, pero antes no. Durante el rodaje yo iba ordenando secuencia a secuencia porque él me dijo, "mire usted, yo tengo la norma de estar durante el montaje", y yo le contesté, "yo tengo la norma de montar solo", y me dijo, "bueno pues me va a perdonar usted, pero por una vez, cambie usted”. Así fui almacenando rollos y rollos y rollos, por problemas de orden técnico o dicción habría que doblar algunas escenas o planos, que él iba anotando, un buen día dijo, "bueno, hay que preparar alguna jornada 
de doblaje”, y producción le dice, “¿contratamos a un director de doblaje?”, y el contesta "no, el director de doblaje es el montador de la película". Así se fue doblando todos los días, con los actores Silvia Pinal, Paco Rabal y Fernando Rey, qué maravilla de compañeros, el dia que terminó el rodaje de la película, Buñuel me dijo, "bueno, cuando usted quiera empezamos a montar", le contesté, "por mí, mañana”. Al día siguiente llegué a las nueve menos cinco, y estaba en el jardín y llega él, se baja del taxi, y mirando el reloj dice, "hemos quedado a las nueve", y al día siguiente, él llega a las nueve menos diez, pero yo había llegado a menos cuarto y entonces dijo, "se ha terminado, venimos a las nueve", y a partir de ese momento, pues viene esa leyenda de que los dos éramos igual de pesados con la puntualidad.

Y empezamos a montar, pero con una particularidad, entonces montábamos en una moviola vertical, en la que tan solo el montador podía ver la película en una lupa de unos diez centímetros. Don Luis dijo, "yo quiero una silla baja”, y se sentó a mi lado. La película había que sujetarla con dos dedos haciendo un bucle para que no saltara, con mi lápiz graso en la mano, llegué al primer punto donde tenía que empezar el plano, marqué el peine de entrada, que es como nosotros denominábamos a las marcas de entrada y de salida de los planos, para después, en el rodillo, cortar. Yo continué con el segundo plano, continué con el tercero, y él no hablaba, y me volví pensando que se habría dormido. Resulta que él no miraba la lupa miraba el paso de la pelicula por mis dedos al hacer el bucle, cuando me doy cuenta le digo digo, "pero don Luis, usted no puede ver, yo le hago hueco", "yo estoy aquí perfecto y lo veo perfectamente", y entonces digo, cómo ve usted lo marcado", "yo hasta el momento no le he mandado nada, usted siga", y así fuimos trabajando, y llega un momento en el que digo, estoy ya no es serio, “usted me pide que siga, ¿qué quiere, que me tire al pozo?”. Así terminó el primer día de trabajo, y así continué montando hasta que llegó la escena de los mendigos en la que, efectivamente, había muchos planos para utilizar en distintas posiciones, por primera vez en mi vida decidí hacer una escaleta, y fui escribiendo y numerando los planos, él movía la cabeza, y yo daba marcha atrás para marcar o fragmento de plano, y toma nota él me decía, "pero, ¿̇por qué vuelve usted otra vez atrás?, “ verá, es que tengo que coger un nuevo trozo para una reacción...”, 
como sin creérselo dice ,"no diga nada, siga usted, siga usted", y de pronto, a las once de la mañana, se levanta y dice, "mire Pedro, lo siento, pero me tengo que marchar, yo hoy no me encuentro bien", y le digo, "pero Don Luis, ¿borro todas las marcas y empezamos de nuevo?", “usted siga, con lo suyo, no, no, no, no...”, y a todo esto, poniéndose la gabardina, se puso su gorra, cogió su paraguas y me dejó tirado. Continué marcando y después montando toda la secuencia del baile.

Todos los días desayunábamos juntos en el bar del estudio, él pedía cuatro porras y dos cafés con leche. Yo me tomaba una porra, y él se tomaba tres. Pero esto continuó todavía en Tristana (1970)17, exactamente igual, con el mismo ceremonial todos los días, "aquí tiene, don Pedro, su porra...”

Aquel nuevo día llegó muy sonriente. Cuando estábamos desayunando, me dice, “¿podemos ver su trabajo de ayer en proyección?”, digo, “sí señor”. Y llegamos a proyección, mis ayudantes estaban atrás, en las salas de proyección había unas mesitas, donde podían tomar nota de todo lo que íbamos diciendo el director y el montador. Se proyectó la secuencia y cuando terminó yo estaba callado, se enciende la luz, él tampoco habla, las ayudantes estaban muertas, se podía cortar el silencio, y de pronto dice, “¿podría verlo otra vez?”, digo, "sí señor”, me vuelvo y le hago un gesto a cabina, y cabina vuelve a pasarla. Cuando se termina la proyección, él sigue en silencio, entonces, le pregunto, "bueno, pues usted dirá", y me dice, “¿a usted qué le parece?”, y le digo, "no, ¿qué le parece a usted”, y me dice, ha cometido usted un error imperdonable. La sangre se me quedó helada, “¿y eso?”, "del plano de las zapatillas del lacerado hay un trozo en la misma toma que es mejor que el que usted ha montado”, “¿y el resto?”, y me contesta, “a mí me parece bien, ¿y a usted?”, el cambio de la zapatilla del lacerado fue la única rectificación y según la monté está en la película.

Fue una colaboración inolvidable, un dia le dije "usted siempre está callado, opine que usted es el director", y su respuesta fue, "le voy a decir una cosa, Don Pedro que quiero que recuerde, que yo soy el director, pero en esta sala, usted es el

17. Película española dirigida por Luis Buñuel, protagonizada por Catherine Deneuve, Fernando Rey, Franco Nero y Lola Gaos, entre otros, que fue Nominada al Oscar a Mejor película de habla no inglesa en 1970 y participó en la Sección oficial de largometrajes del Festival de Cannes de ese mismo año. 
montador, usted monte que yo ya he dirigido". Como director y como persona era extraordinario, después llegó toda la cuestión de París ${ }^{18}$, que fue toda una aventura, como no lo sabe nadie, conseguimos llegar a las fechas marcadas, el material llegó a Cannes por coche, por tren, por avión... Yo sí sé cómo llegó, fue el último día del certamen y la otorgaron la Palma de Oro.

\section{¿Cómo fue vuestra colaboración en la segunda película, "Tristana" (1970)?}

Bueno, un buen día, me llaman de Talia Films y me dicen que van a hacer una película con Buñuel en Madrid y que ha pedido, efectivamente, que sea yo el montador. Pepe Puyol, que había sido su ayudante de dirección en Viridiana, recibe una llamada de Don Luis, y le dice, "Pepe, he recibido una carta de un compañero ofreciéndome un montador, pero yo no le quiero contestar, llámele usted por teléfono y dígale, muchas gracias, pero yo ya tengo montador, porque, mientras viva, y quiera seguir colaborando conmigo, Pedro del Rey es mi montador en España”. Él siempre decía una cosa, “algún día reuniré al montador de México, a la montadora de París y usted para ver qué podíamos sacar entre todos".

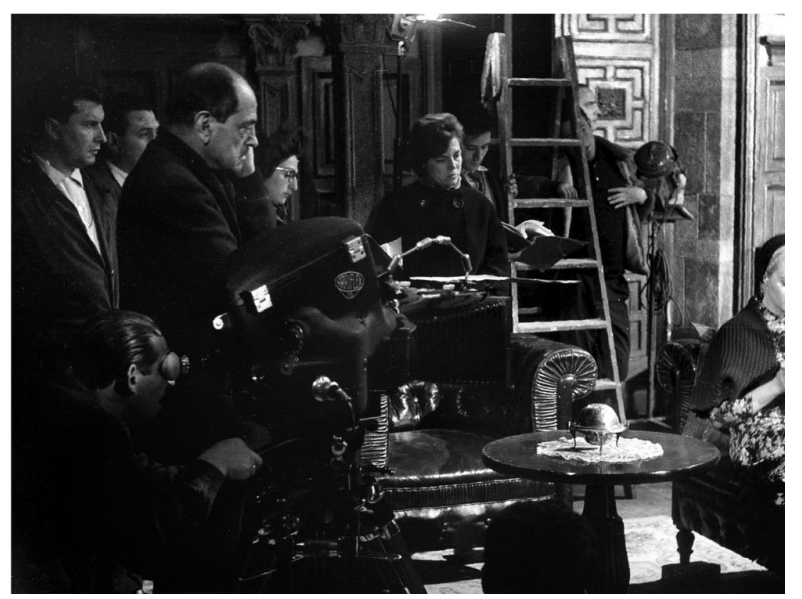

Imagen 5. Luis Buñuel en el set durante el rodaje de Viridiana. Fuente:

https://www.heraldo.es/noticias/ocio-y-cultura/2021/05/17/luis-bunuel-viridiana-aniversariocannes-1491357.html

18. Viridiana de Luis Buñuel, logró conquistar la Palma de Oro en Cannes en el año 1961. 
Era muy fiel con sus colaboradores, así en Tristana repetimos el director de fotografía, su ayudante de dirección y yo. Eso sí, tomándome el pelo a todas horas. Cuando montamos Tristana, en los estudios Verona ${ }^{19}$, en las cercanías de Madrid, hay un mesón muy célebre. Allí íbamos todos los días a comer a la una. Él me empezaba a dar la lata a la una menos cuarto, diciendo, "don Pedro, vamos a llegar tarde", y comíamos solos, que es lo que él quería, que no hubiera nadie. Todos los días con el mismo camarero y en la misma mesa. Todavía existe el rincón donde comíamos. Él decía al camarero, "por favor, tráiganos usted una jarra de vino, y un plato de jamón, pero el vino antes porque mi amigo es un poco borracho”. Esa era su cantinela diaria. Más tarde, en uno de los viajes que él hizo a Madrid, me escribió preguntándome si me parecía bien, quedamos a los dos y media, cuando salimos del restaurante eran las nueve de la noche. Toda la tarde hablando de nuestras aventuras, de nuestras familias... Él, en un momento, cuando se terminó Viridiana, y estando yo en París, aquel célebre día de La Coppule, él me dijo, "llame usted a su mujer", yo tenía entonces.... Acababa de nacer mi hija, la mayor, y me dice "y dígale a su mujer que prepare a la niña, que se venga para acá, porque así nos vamos todos a México”. Y entonces, yo le dije, “pues no lo sé...”, y dijo, “mire, la cosa está clara. Si nos llaman de Europa, usted y yo nos venimos a Europa, y se queda, la abuela, con la niña y con su mujer, y ya se quedan en México”. Entonces, yo llamé aquella misma noche a mi mujer enloquecido, porque yo me hubiera ido al fin del mundo, y le dije, “oye, mira, que es que me dice Don Luis esto...” Y dijo ella, “dile que yo no pienso ir a México nunca en mi vida”. Aquello Don Luis nunca me lo perdonó. Cuando él tenía el guion de El Monje (1975) 20, me dijo, "pues ahora resulta que me ofrecen de Inglaterra que vaya a hacer El Monje, y le dije, "me voy con usted”, y me contestó, "no, porque usted me traicionó una vez". Tenía una memoria de elefante para eso, dije, "yo no lo he traicionado a usted en mi vida”, y él me decía, "sí, sí, sí, yo le dije que usted se viniera conmigo a México, y usted no se quiso venir", digo, "bueno,

\footnotetext{
${ }^{19}$. Los Estudios Verona, ubicados en Colmenar Viejo (Madrid), comenzaron su actividad como zona de rodaje en exteriores de los Estudios Roma. En estos estudios rodaron grandes directores nacionales e internacionales como el propio Luis Buñuel, Pedro Almodóvar p George Cukor, entre muchos otros.

${ }^{20}$. Película francesa dirigida por Adonis Kyrou, con guion de Luis Buñuel, protagonizada por Franco Nero, Nathalie Delon, Nicol Williamson y Nadja Tiller, entre otros.
} 
pues nada...”. Y esa es una historia larga, muy bonita, y de gran recuerdo en mi vida.

Retomando un poquito el recorrido de esta charla, hemos estado hablando un poco de Luis Buñuel, también hemos hablado antes un poco de Carlos Saura, al cual, según comentabas, conociste a través de Juan Julio Baena con el montaje de La Chunga, y luego, posteriormente, trabajaste con él también en Los Golfos, según has mencionado antes, también, más adelante, volvió a contar contigo en Carmen y en El amor brujo, si no me equivoco, y en Llanto por un bandido. ¿Cómo fue tu relación con Carlos Saura en el trabajo de montaje de estos títulos?

Bueno, Los Golfos (1960) fue una gozada, porque era prácticamente una improvisación, era como un ejercicio, que Carlos Saura tuvo que trabajar con aquellos chicos, que no eran actores y que más de uno hasta podía ser un ratero auténtico, no fue fácil, pero Carlos, hizo una película muy interesante. Yo, tuve la fortuna de llevar la documentación de la misma a París cuando la presentaron en Cannes,

En la época de Franco me he enfrenté, en más de una ocasión a la censura, y no he estado de acuerdo con nada porque yo soy apolítico, si tristemente mi padre murió en el año 1939 antes de terminar la guerra, ¿cómo voy a querer saber yo nada de política?

Comentas en tu libro de Carmen (1983) que guardas un recuerdo imborrable del montaje de esta película.

Sí, bueno, un día me llamó Gustavo Quintana, que era el jefe de producción de la productora de Emiliano Piedra, me llama para montar Carmen, pero con una condición, dedicar tu tiempo exclusivamente a la película, porque él sabía que yo montaba una o dos o tres películas a la vez, y el quería dedicación absoluta. Y entonces, le dije, "pues mira”, justamente el mismo día que vosotros empezáis a rodar, el día, me parece que se empezaba a rodar el 7 de enero, creo recordar, el día 7 de enero empezaba también Antonio del Real con una película que ya tenía 
yo apalabrada, y ya no le iba a decir que no. Y entonces le dije, "mira, yo no puedo, ya he dado mi palabra, y lo siento en el alma, así es que, dile que no", bueno, pues efectivamente, Carlos dijo, "bueno pues nada, qué le vamos a hacer". Y al día siguiente, me vuelve a llamar Gustavo Quintana, "oye, quieres que hablemos con Antonio del Real", "no, ni se os ocurra, vamos, de ninguna de las maneras". Bueno, pues entonces, un día, justamente había terminado yo una película y me había venido unos días a mi casa de la sierra, y estaba yo solo, no había venido con mi familia, me había venido con mi perra exclusivamente, suena el teléfono y me dice Gustavo, "oye Pedro, que te vengas inmediatamente a la Casa de Campo", que es donde se rodaba Carmen, y le contestó querido Gustavo yo estoy en Navacerrada en este momento", "que te vengas inmediatamente, que es importantísimo porque Emiliano necesita hablar contigo". Bueno, pues nada, entonces, le quita el teléfono Emiliano y me dice: "oye Pedrito, tengo que hablar contigo", con lo cual, dejé a mi perrita en casa y me fui al lugar de rodaje.

Llegué allí y estaban Carlos, Emiliano y Gustavo juntos, "bueno, que no va a haber ningún problema”, me dice Emiliano, digo “¿qué problema puede haber?”, "no, mira", y dice Carlos, "Pedrito vamos a hacer la película juntos, pero tienes que dedicarla su tiempo", y le digo, "oye, tú qué quieres ḋla mañana o la tarde?, "no, yo desde que termine el rodaje quiero que el montaje esté listo", "lo vas a tener", le dije, hablé con Antonio del Real y le digo, "Antonio, tú y yo vamos a trabajar de ocho a tres", "perfecto Pedro, sin ningún problema”, y en efecto no hubo problema alguno. Pero llegó la Tabacalera, que era un poquito complicada en su montaje, yo tenía el material preparado en la estantería unos días, pero Carlos me decía, "Pedro, yo te pido por favor, que la tabacalera la montemos juntos", y yo no hacía más que mirar los rollos en la estantería, y mi mujer, que entonces era mi ayudante, me decía "no mires esas cajas, esas cajas que no...”, y a la tercera le dije, "los rollos a la moviola", y me monté la tabacalera.

Cuando llegó llegó Carlos por la tarde me dijo, “¿sabes lo que te digo?, que hoy vengo dispuesto a meter mano a la tabacalera", digo, "ya está metida", y dice, “¿qué?”, “que la he montado", "Pedro, me has matado, ay por Dios...” Bueno, pues la colocamos en la moviola, la vimos los dos juntos, no comentó nada al principio, 
me dijo, “¿por qué no te vas al bar?”. Me fui al bar, el la vió como cuatro veces, apareció en el bar y dijo, "bueno, vamos a ver una cosa, hay algo que te quiero proponer", digo "vale", "mira, se rodaron unos planos cámara en mano, unos primeros planos, del final, para jugar uno con otro...”, y esos, yo no los había montado porque no me encajaban demasiado, porque me rompían el estilo que llevaba el baile, y me dice, "pues estos me gustaría incluirlos". Los marcamos, los coloqué y ahí está la tabacalera.

\section{Incorporando esas sugerencias que él te dijo, pero por lo demás, está como tú la montaste, ¿̇verdad?...}

Exactamente, la tabacalera la monté íntegramente yo solo, y te diré una cosa, en el Festival de Cannes, cuando terminó la tabacalera, fue tal el aplauso en el festival que a mí me temblaban las piernas. Yo tenía una emoción... Y cuando terminó la película, fue una cosa verdaderamente increíble, de esos momentos que se te pone el pelo de punta. Y bueno, pues después de hacer “Carmen”, hizo otra película con su anterior montador, porque se lo pidió, yo estaba en Suiza terminando una película, es más, aquella noche había terminado de mezclar la película, los productores me llamaron, "Pedro, veniros a casa", mi mujer era mi ayudante, "he recibido una llamada telefónica de Emiliano el sobrino de Emiliano Piedra, que te pongas en comunicación con ellos inmediatamente", y desde allí mismo le llamé “¿qué pasa, Emi?”, “que te vengas para acá que tienes El Amor Brujo (1986) ${ }^{21}$ esperándote”, digo, “¿qué?”, dice, “sí”, digo, “bueno, pero qué es lo que ha pasado", y dice, "pues que el otro montador tenia otra película, y al enterarse Carlos ha dicho, "que llamen a Pedro".

Hicimos El Amor Brujo, después La noche oscura (1989)²2, después El Dorado (1988), que montamos íntegramente en Costa Rica, después, también me

\footnotetext{
${ }^{21}$. Película española dirigida por Carlos Saura, con guion del propio Saura y Antonio Gades, protagonizada por Antonio Gades, Cristina Hoyos, Juan Antonio Jiménez o Emma Penella, entre otros. Ganadora de los Goyas a Mejor Fotografía y Diseño de Vestuario en el año 1986, con nominación también a Mejor montaje para Pedro del Rey.

${ }^{22}$. Coproducción hispano-francesa dirigida por Carlos Saura, con guion del propio Saura, protagonizada por Juan Diego, Julie Delphy, Fernando Guillén, Manuel de Blas o María Elena Flores, entre otros. La película obtuvo ocho nominaciones en los Premios Goya del año 1989, incluyendo Mejor actor, y participó en la Sección oficial de largometrajes del Festival de Berlín de ese mismo año.
} 
llamaron para hacer otra película con Carlos, pero yo estaba haciendo Madregilda con Francisco Regueiro (1993)²3, y tuve que decir que me era imposible, pero eso no dice nada, por una razón fundamental, porque yo sigo admirando y queriendo a Carlos, como director y como amigo, como director es una figura increíble.

\section{Algún consejo o alguna recomendación para los jóvenes que quieran dedicarse a esta maravillosa profesión que es la del montaje cinematográfico.}

Yo les diría que que recuerden que el tamaño y ángulos de los planos no es un capricho, cada cambio de ángulo o tamaño de plano ha de corresponder a un diseño lógico de narración por eso debe de ser de obligado cumplimiento que presten atención antes de cortar un plano, que repasen lo escrito en el guion una y otra vez hasta verlo compaginado en su cabeza. Dejad la velocidad y las prisas para más adelante, comprendo las ansias de cortar y pegar, pero es muy importante tratar de encontrar la fórmula de llevar a cabo vuestro trabajo sin tener que tocar el material, eso es una de las cosas más importantes, porque lógicamente el alumno al encontrarse, ante una pantalla y unas teclas dice, esto es muy fácil, mira, ya tengo el primer plano en la pantalla, corto aquí toco otra tecla y tengo el segundo dispuesto para cortar y pegar, pero eso siempre será cortar y pegar pero no montar. Cuando veo algunas películas, en la actualidad, creo ver una sucesión de planos sin sentido, cambiando de plano por frase, eludiendo la escucha y reacción del interlocutor, para mí, a veces, es más importante la reacción del que escucha que la frase del que habla.

Al que empieza en una escuela le diré que preste atención al profesional que enseña, que escuche, que no se precipite en montar que frene y piense en lo que está haciendo y en lo que quiere decir en la sucesión de las imágenes. Mi consejo

\footnotetext{
23. Comedia dirigida por Francisco Regueiro, con guion de Ángel Fernández Santos y el propio Francisco Regueiro, protagonizada por José Sacristán, Juean Echanove, Barbara Auer y Fernando Rey, entre otros. La película obtuvo siete nominaciones en los Premios Goya de 1997 y conquistó la Concha de Plata al mejor actor del Festival de San Sebastian para Juan Echanove.
} 
es que piensen siempre antes de cortar, sea en digital o como sea, que piensen siempre antes de cortar un plano.

\section{Referencias bibliográficas}

Del Rey, P., comunicación personal, 26 de febrero de 2021.

Del Rey, P. (2002). Montaje. Una profesión de cine. Barcelona: Ariel.

International Movie Data Base. (s.f.) Filmografía Pedro del Rey. https://www.imdb.com/name/nmo215811/

Lafont, I. (octubre, 19, 2010). "El hombre con el Rólex de Buñuel". https://elpais.com/diario/2010/10/19/madrid/1287487469 850215.ht $\underline{\mathrm{ml}}$ 